\title{
Effectiveness of photodynamic therapy and sodium hypochlorite on root canal system infected with Enterococcus faecalis - an in vitro study
}

Matheus Albino Souza ${ }^{\mathrm{a}}$, Liviu Steier ${ }^{\mathrm{b}}$, Giampiero Rossi-Fedele ${ }^{\mathrm{c}}$, Valdir Barth Júnior ${ }^{\mathrm{d}}$, Silvia Dias de Oliveira ${ }^{d}$, José Antônio Poli de Figueiredo ${ }^{e}$

\begin{abstract}
Objective: The purpose of this study was to evaluate, in vitro, the effectiveness of photodynamic therapy and sodium hypochlorite over root canal system infected with Enterococcus faecalis.

Methods: The root canals of 45 single-rooted human extracted teeth were enlarged up to a file 60, autoclaved, inoculated with Enterococcus faecalis and incubated for 30 days. The samples were divided into five groups ( $\mathrm{G} 1-\mathrm{n}=5$; $\mathrm{G} 2-\mathrm{G} 5-\mathrm{n}=10$ ) according to the protocol of decontamination: G1 (negative control) - no procedure was performed; G2 - distilled water; G3 - photodynamic therapy (PDT); G4 - 2.5\% sodium hypochlorite (NaOCl); and G5 - 2.5\% $\mathrm{NaOCl}+$ PDT. Scanning electron microscopy (SEM) were performed to evaluate the effectiveness of proposed treatments. The assessment was made by images of each third at 5000x magnification for the canal wall and 10000x for the exposed tubule area. The presence of bacteria was scored by position ranks from 1 to 45 , where the higher the value, the cleanliness of the sample. Data were subjected to one-way ANOVA followed by post-hoc Tukey test $(\alpha=0.05)$.

Results: Group $4(2.5 \% \mathrm{NaOCl})$ and $5(2.5 \% \mathrm{NaOCl}+$ PDT) had the highest mean of position ranks for all thirds of the root canal in the canal wall, which was statistically different from groups 1,2 and $3(p<0.05)$. Group 3 (PDT), group $4(2.5 \% \mathrm{NaOCl})$ and $5(2.5 \% \mathrm{NaOCl}+\mathrm{PDT})$ had the highest mean of position ranks in the exposed tubule area, which was statistically different from groups 1 and 2 $(p<0.05)$.
\end{abstract}

Conclusion: the association of $2.5 \%$ sodium hypochlorite + photodynamic therapy can be considered an effective protocol for the elimination of Enterococcus faecalis.

Key words: Photodynamic therapy; Sodium hypochlorite; Enterococcus faecalis

\section{Eficácia da terapia fotodinâmica e do hipoclorito de sódio sobre o sistema de canais radiculares infectado com Enterococcus faecalis - um estudo in vitro}

\section{RESUMO}

Objetivo: o propósito deste estudo foi avaliar, in vitro, a eficácia da terapia fotodinâmica e do hipoclorito de sódio sobre o sistema de canais radiculares infectados com Enterococcus faecalis.

Metodologia: Os canais radiculares de 45 dentes humanos extraídos unirradiculares foram ampliados até a lima 60, autoclavados, inoculados com Enterococcus faecalis e incubados por 30 dias. As amostras foram divididas em cinco grupos ( $G 1-n=5$; $G 2-G 5-n=10$ ) de acordo com o protocolo de descontaminação: $G 1$ (controle negativo) - não foi realizado procedimento; G2 - água destilada; G3 - terapia fotodinâmica; G4 - hipoclorito de sódio 2,5\%; G5 - hipoclorito de sódio 2,5\%+terapia fotodinâmica. Microscopia eletrônica de varredura foi realizada para avaliar a eficácia dos tratamentos propostos. A avaliação foi feita através de imagens de cada terço a 5000x de magnificação nas paredes do canal e 10000x na profundidade dos túbulos dentinários. A presença de bacterias foi determinada por intermédio de rank de posições a partir de 1 até 45 , onde quanto maior o valor, maior a limpeza da amostra. Os dados foram submetidos a one-way ANOVA seguido por post-hoc de Tukey $(\alpha=0.05)$. Resultados: Grupo 4 ( $\mathrm{NaOCl}$ 2,5\%) e 5 ( $\mathrm{NaOCl}$ 2,5\%+PDT) obtiveram a maior media de posição de ranks para todos os terços do canal radicular na parede do canal, o que foi estatisticamente diferente dos grupos 1,2 e 3 $(p<0.05)$. Grupo $3(\mathrm{PDT})$, grupo $4(\mathrm{NaOCl} 2,5 \%)$ e $5(\mathrm{NaOCl} 2,5 \%+\mathrm{PDT})$ obtiveram a maior méida de posição de ranks para todos os terços do canal radicular na profundidade dos túbulos dentinários, o que foi estatisticamente diferente dos grupos 1 e $2(p<0,05)$

Conclusão: A associação de hipoclorito de sódio 2,5\% e terapia fotodinâmica pode ser considerado um protocolo efetivo na eliminação de Enterococcus faecalis.

Palavras-chave: Enterococcus faecalis; Hipoclorito de sódio; Terapia fotodinâmica a School of Dentistry, University of Passo Fundo, Passo Fundo, RS, Brazil.

Warwick Dentistry, Warwick Medical School, Warwick, United Kingdom.

${ }^{c}$ School of Dentistry, University of Adelaide Adelaide, Australia.

d School of Biosciences, Pontificial Catholic University of Rio Grande do Sul, Porto Alegre, RS, Brazil.

e School of Dentistry, Pontifical Catholic University of Rio Grande do Sul, Porto Alegre, RS, Brazil.

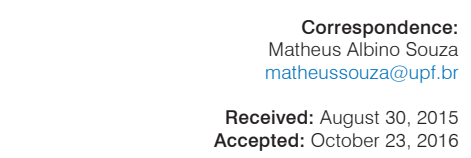

Conflict of Interests: The authors state that there are no financial and personal conflicts of interest that could have inappropriately influenced their work.

Copyright: (C) 2016 Souza et al licensee EDIPUCRS.

This work is licensed under a Creative Commons Attribution 4.0 International License.

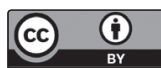




\section{INTRODUCTION}

Microorganisms and their products are the main aetiological factor of pulpal and periapical pathologies [1,2]. Despite the prevalence of anaerobic bacteria within infected root canals [3], aerobic or facultative anaerobic species have also been found in endodontic microbiota [4,5]. Furthermore, due to the anatomical complexity of the root canal system, organic tissues and some bacteria such as Enterococcus faecalis, which are located at depth in the dentinal tubules, as well as in isthmus and ramification areas, cannot always be reached [6].

Enterococcus faecalis is an anaerobic facultative microorganism, which is highly resistant to conventional chemo-mechanical preparation and is usually found in cases of failure of root canal treatment [7]. This microorganism has several virulence factors and the ability to withstand prolonged periods of nutrient limitation, thus persisting as a pathogen in the root canal $[8,9]$.

Sodium hypochlorite is the most commonly used root canal irrigant into root canal therapy, due its broad antimicrobial spectrum [10-12] and its ability to promote organic tissue dissolution [13-14]. However, sodium hypochlorite is highly irritating when in contact with periapical tissues [15], reduces the resistance of teeth to fracture [16] and interferes negatively with bond strength of adhesive restorations to dentin $[17,18]$. Because of the adverse effects of this irrigant, researchers have developed alternative resources in order to promote decontamination of root canal system.

Photodynamic therapy (PDT) has been considered a new therapeutic modality to improve root canal disinfection, involving the association between a light source generated by a low-power laser and a nontoxic photosensitizer [19]. The photosensitizer stimulated by the laser light reacts with molecular oxygen, generating reactive oxygen species. These species act in bacterial cellular components through oxidation or reduction reactions, inducing the death of microorganisms [20]. However, the cleaning ability of photodynamic therapy associated to endodontic irrigants needs further elucidation

The aim of this study was to evaluate, in vitro, the effectiveness of photodynamic therapy and sodium hypochlorite over root canal system infected with Enterococcus faecalis.

\section{METHODS}

This study was approved by the Ethics Commission of the Pontifical Catholic University of Rio Grande do Sul (Porto Alegre, RS, Brazil) (protocol 1637/09).

\section{Sample obtaining and preparation}

Forty-five single-rooted human extracted teeth were used in the present study. The teeth were obtained from Tooth Bank of School of Dentistry of Pontifical Catholic University of Rio Grande do Sul. Dental crowns were sectioned with a rotating diamond saw $(\# 911 \mathrm{H}$ - Brasseler, Savannah, GA, United States) set at $20.000 \mathrm{rpm}$ under water-coolant, so that all of the roots retained a length of $15 \mathrm{~mm}$. The presence of a single root canal was detected using clinical surgical microscope (Opto, São Carlos, SP, Brazil), in 20x of magnification.

All roots were prepared using the same protocol in order to remove pulp tissue and to standardise the canal diameter. The cervical third was prepared using Largo drills \#3 and \#4 (Dentsply-Maillefer). The working length was established by introducing a K-file \#10 (DentsplyMaillefer) in the canal until its tip was visualised at the apical foramen. From this measure, $1 \mathrm{~mm}$ was removed, establishing the working length. The roots were prepared up to instrument \#60 (Dentsply-Maillefer), by serial instrumentation, using K-files (Dentsiply-Maillefer) and irrigation with distilled water (Decloquimis, São Paulo, SP, Brazil). Then, a final rinse with 17\% EDTA (Iodontosul, Porto Alegre, RS, Brazil) for 3 minutes under agitation with K-file \#60 (Dentsply-Maillefer) was performed for smear layer removal.

Each root was fixed with Putty-C Silicone for Impression (Silon2APS - Dentsply, Petrópolis, RJ, Brazil) in a plastic micro-tube (Axygen Inc, Union City, CA, USA), so that it remained upright with the cervical portion facing upwards. The teeth were divided into five groups, and each group was placed in a polypropylene box (Heathrow Scientific, Vernon Hills, IL, Unite States). The samples were submitted to sterilization at $120^{\circ} \mathrm{C}$ in an autoclave (Dabi Atlante, Ribeirão Preto, SP, Brazil) for a period of 30 minutes.

\section{Culture and inoculum preparation}

The culture and inoculum preparations were performed according to a previous study [11]. The reference strain was Enterococcus faecalis (ATCC 19433), which was obtained and activated in the Laboratory of Immunology and Microbiology, School of Biosciences, Pontifical Catholic University of Rio Grande do Sul. The bacteria were cultivated in brain-heart infusion (BHI) broth for 18 to 24 hours at $37^{\circ} \mathrm{C}$ in a bacteriological incubator.

In each one of the 45 previously sterilised samples, $100 \mu \mathrm{L}$ of the culture of Enterococcus faecalis was inoculated into the root canal. After this procedure, the sterile BHI was added into the root canal, so that it was completely filled with the culture. The culture of Enterococcus faecalis was maintained for 30 days in order to promote bacterial growth, renewing the BHI every 48 hours. All procedures were performed under aseptic conditions in a laminar flow hood. Once a week, an aliquot of BHI from a randomly selected tooth from each group was submitted to Gram staining and cultured on blood agar followed by catalase and esculin tests to verify the absence of contamination with other microorganisms.

\section{Classification of treatment groups}

After the period of contamination, the 45 samples were irrigated with $5 \mathrm{~mL}$ of distilled water and distributed into five 
groups, being 5 in control group (G1) and 10 in experimental groups (G2-G5), according to the decontamination procedure, as follows:

Group 1 (negative control) - no decontamination procedure was performed.

Group 2 (distilled water) - the root canal was filled with $2 \mathrm{~mL}$ of distilled water (Decloquimis, São Paulo, SP, Brazil). The solution was agitated with $\mathrm{k}$-file \#15 for a period of 60 seconds and remained in the root canal space for 3 minutes. After that, the solution was renewed for another cycle. In total, there were four cycles of decontamination.

Group 3 (PDT) - the root canal was filled with $2 \mathrm{~mL}$ of $0.01 \%$ methylene blue (MB). The photosensitizer remained into the canal space for 5 minutes (pre-irradiation time). After that, diode laser (Therapy XT - DMC Equipamentos, São Carlos, SP, Brazil), with $100 \mathrm{~mW} \pm 20 \%$ of real power and red (650-670nm wavelength) continuous emission, with an intra-canal fibre attached, was used. The root canals were irradiated for 90 seconds, with the intra-canal fibre placed $2 \mathrm{~mm}$ short of the working length. As recommended by the manufacturer, a total dose of $9 \mathrm{~J}$ was delivered into the root canal of each sample during the 90 seconds, following three steps: $1: 4 \mathrm{~J}$ in a fluency rate of $140 \mathrm{~J} / \mathrm{cm}^{2}$ (40 seconds); 2: $4 \mathrm{~J}$ in a fluency rate of $140 \mathrm{~J} / \mathrm{cm}^{2}(40$ seconds) and $3: 1 \mathrm{~J}$ in a fluency rate of $35 \mathrm{~J} / \mathrm{cm}^{2}$ (10 seconds).

Group $4(2.5 \% \mathrm{NaOCl})$ - the root canal was filled with $2 \mathrm{~mL}$ of $2.5 \% \mathrm{NaOCl}$ (Decloquimis, São Paulo, SP, Brazil). The solution was agitated with k-file \#15 for a period of 60 seconds and remained in the root canal space for 3 minutes. After that, the solution was renewed for another cycle. In total, there were four cycles of decontamination.

Group $5(2.5 \% \mathrm{NaOCl}+\mathrm{PDT})$ - the same procedure described in group 4 was performed in this group. After that, the photodynamic therapy protocol was performed as described in group 3.

After the respective treatments, the root canal samples of each group were irrigated with $5 \mathrm{~mL}$ of distilled water.

\section{SEM preparation and analysis}

Scanning electron microscopy (SEM) was performed at Centre for Electron Microscopy and Microanalysis at the Technologic Park of University of Passo Fundo. After microbiological sampling, the roots were fixed for 7 days in $2 \%$ glutaraldehyde and washed three times for 30 minutes in a $1: 1$ ratio of $0.2 \mathrm{M}$ phosphate buffer and distilled water. After dehydration, the roots were longitudinally sectioned, providing two halves of each sample. The samples were placed on stubs with the portion of the root canal positioned upward and coated with gold-palladium for conducting electrons. Image acquisition was performed by SEM (Philips XL 30, Eindhoven, Netherlands), using the backscattering resource (BSE).

The image records were made at 5000x in the canal wall of the root canal space and 10000x in the exposed tubule area. One single observer blinded has assessed and evaluated the images according to the presence of bacteria through a position rank score system, at each third of the root canal. Forty-five images of each third of samples were classified from 1 to 45. Adopting the PowerPoint program (Microsoft Corp, Redmond, WA, United States), each image occupied a slide, which was transferred to the computer screen in the form of presentation. The images were modified in position according to the level of contamination found, so that number 1 was the most contaminated and number 45 was the least contaminated. This classification by rank was performed on each third (coronal, middle, and apical) by the location of the image (canal wall and exposed tubule area). Then, for each third and for each image location, the average position of the group was calculated.

\section{Statistical analysis}

The one-way ANOVA test was applied followed by Tukey's post hoc procedure, at a significance level of 5\%. Data were analysed using SPSS version 17.0 (SPSS, Chicago, IL, United States).

\section{RESULTS}

The mean and standard deviation of position ranks of different decontamination protocols are shown in Table 1. Figure 1 illustrates the difference in the mean of position ranks between the groups in the canal wall and exposed tubule area respectively.

Table 1. Mean and standard deviation of position ranks of the groups tested in the apical, middle and coronal thirds of the canal wall and exposed tubule area.

\begin{tabular}{|c|c|c|c|c|c|c|}
\hline \multirow{2}{*}{ Group } & \multicolumn{2}{|c|}{ Apical third } & \multicolumn{2}{|c|}{ Medium third } & \multicolumn{2}{|c|}{ Coronal third } \\
\hline & Canal wall & Exposed tubule & Canal wall & Exposed tubule & Canal wall & Exposed tubule \\
\hline 1 & $6.2 \pm 4.9^{\mathrm{A}, \mathrm{a}}$ & $5.8 \pm 5.5^{\mathrm{A}, \mathrm{a}}$ & $7.0 \pm 9.6^{\mathrm{A}, \mathrm{a}}$ & $6.0 \pm 3.1^{\mathrm{A}, \mathrm{a}}$ & $3.0 \pm 1.5^{\mathrm{A}, \mathrm{a}}$ & $7.8 \pm 8.2^{\mathrm{A}, \mathrm{a}}$ \\
\hline 2 & $17.6 \pm 11.1^{\mathrm{B}, \mathrm{a}}$ & $10.1 \pm 5.5^{\mathrm{A}, \mathrm{a}}$ & $10.9 \pm 6.0^{A, a}$ & $11.7 \pm 7.1^{\mathrm{A}, \mathrm{a}}$ & $18.1 \pm 10.0^{\mathrm{B}, \mathrm{a}}$ & $11.6 \pm 8.9^{\mathrm{A}, \mathrm{a}}$ \\
\hline 3 & $16.3 \pm 9.2^{\mathrm{B}, \mathrm{a}}$ & $30.7 \pm 11.8^{\mathrm{B}, \mathrm{a}}$ & $20.6 \pm 7.5^{\mathrm{B}, \mathrm{a}}$ & $24.4 \pm 11.7^{\mathrm{B}, \mathrm{a}}$ & $21.5 \pm 10.3^{\mathrm{B}, \mathrm{a}}$ & $25.1 \pm 10.4^{\mathrm{B}, \mathrm{a}}$ \\
\hline 4 & $27.8 \pm 7.8^{\mathrm{C}, \mathrm{a}}$ & $26.6 \pm 7.4^{\mathrm{B}, \mathrm{a}}$ & $32.5 \pm 8.9^{\mathrm{C}, \mathrm{a}}$ & $30.3 \pm 6.5^{\mathrm{B}, \mathrm{a}}$ & $26.8 \pm 11.0^{\mathrm{C}, \mathrm{a}}$ & $26.5 \pm 8.8^{\mathrm{B}, \mathrm{a}}$ \\
\hline 5 & $38.6 \pm 4.8^{\mathrm{C}, \mathrm{a}}$ & $33.2 \pm 7.6^{\mathrm{B}, \mathrm{a}}$ & $36.0 \pm 5.4^{\mathrm{C}, \mathrm{a}}$ & $34.1 \pm 10.2^{\mathrm{B}, \mathrm{a}}$ & $35.6 \pm 8.2^{\mathrm{C}, \mathrm{a}}$ & $36.4 \pm 7.4^{\mathrm{B}, \mathrm{a}}$ \\
\hline
\end{tabular}

The superscript capital letters indicate, in each column, values statistically significant $(p<0.05)$.

The superscript lowercase letters indicate, in the row, values statistically significant $(p<0.05)$ in the different thirds. 


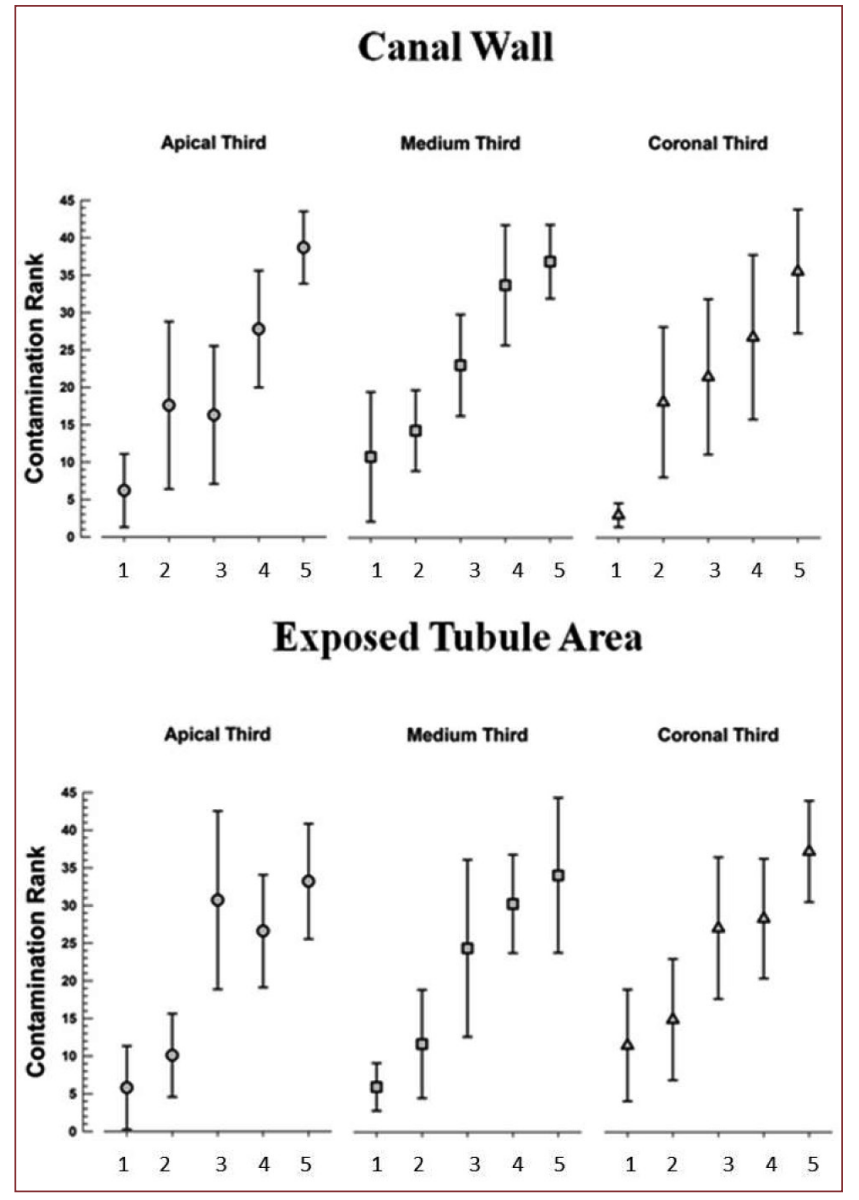

Figure 1. graphs showing position rank means of the groups tested at the apical, middle and coronal thirds of the canal wall and exposed tubule area.

In all thirds of root canals, group $4(2.5 \% \mathrm{NaOCl})$ and $5(2.5 \% \mathrm{NaOCl}+\mathrm{PDT})$ had the highest mean of position ranks in the canal wall, which was statistically different from groups 1, 2 and $3(p<0.05)$. However, there were no statistically significant differences between groups 4 and 5 , as well as the root canal thirds which were evaluated in these groups. At the same time, group 3 (PDT), group 4 $(2.5 \% \mathrm{NaOCl})$ and $5(2.5 \% \mathrm{NaOCl}+\mathrm{PDT})$ had the highest mean of position ranks in the exposed tubule area in all thirds of root canal, which was statistically different from groups 1 and $2(p<0.05)$. However, there were no statistically significant differences between groups 3,4 and 5 , as well as the root canal thirds which were evaluated in these groups. Figure 2 shows SEM photomicrographs of each group at the canal wall (5000x) and exposed tubule area $(10000 x)$ respectively.

\section{DISCUSSION}

The model of bacterial growth used in this study has already been reported in previous studies that were focused on antimicrobial strategies against Enterococcus faecalis.

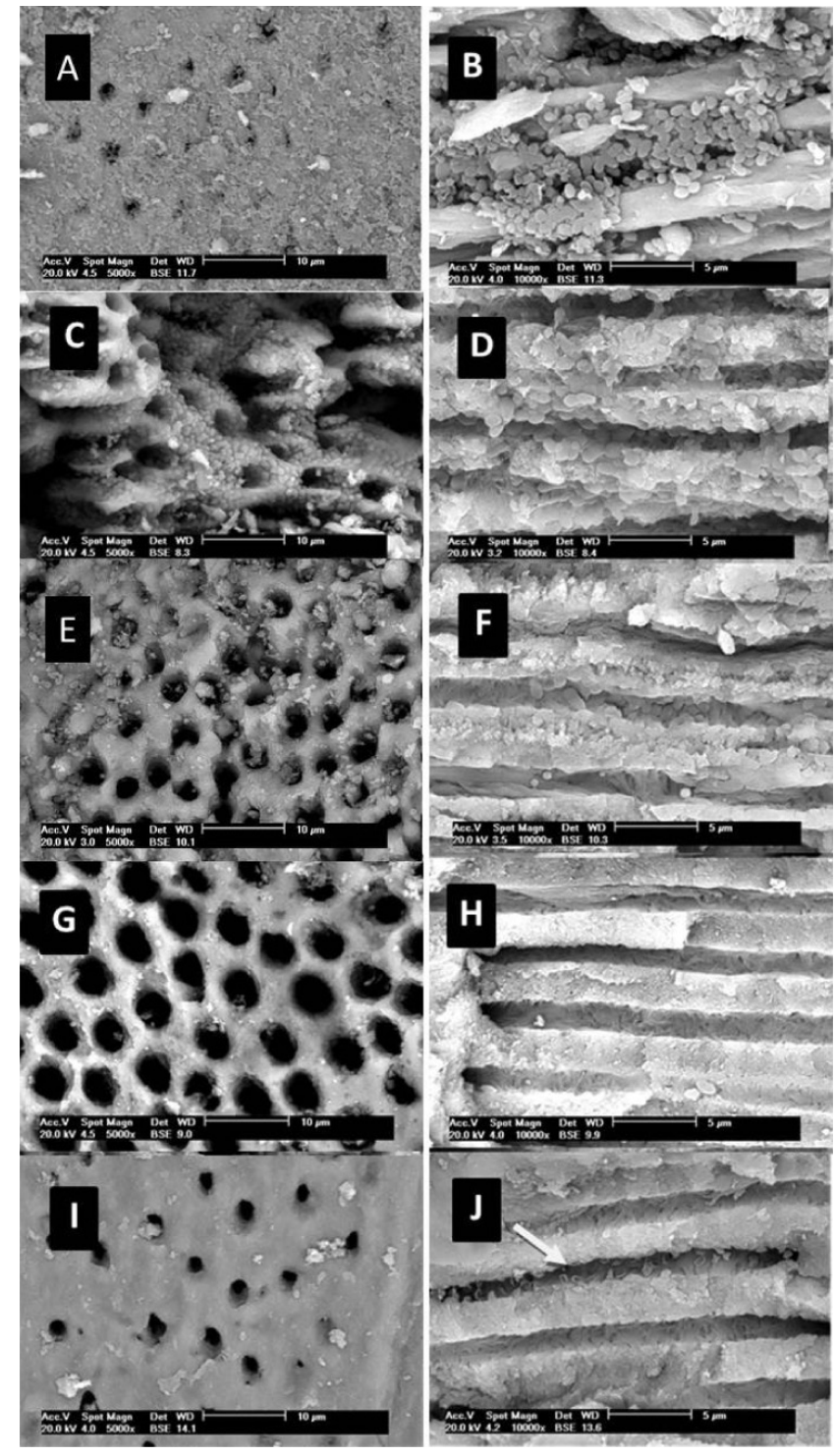

Figure 2. SEM images of the tested groups at the canal wall (5000x) and exposed tubule area (10000x): A - G1 (no treatment) at the canal wall; B - G1 (no treatment) at the exposed tubule area; C - G2(distilled water) at the canal wall; D - G2(distilled water) at the exposed tubule area; E - G3(PDT) at the canal wall; F - G3(PDT) at the exposed tubule area; $\mathrm{G}-\mathrm{G} 4(\mathrm{NaOCl})$ at the canal wall; $\mathrm{H}-\mathrm{G} 4(\mathrm{NaOCl})$ at the exposed tubule area; I - G5(NaOCl+PDT) at the canal wall; $J-\mathrm{G} 5(\mathrm{NaOCl}+\mathrm{PDT})$ at the exposed tubule area

However, there is no consensus in the literature about the time to obtain this bacterial growth, ranging from 24 hours [21-23] to 50 days [24]. In the present study, the bacterial growth was performed during a period of 30 days. From that, this period would be enough to form a structured biofilm and the decontamination protocols could be effectively tested, mimicking the clinical situation in a better way. Moreover, Enterococcus faecalis was chosen because of its ability to penetrate dentinal tubules and colonise the root canal system [25].

The root canals from all extracted teeth were enlarged in the same way in order to standardise the canal diameter 
and create an adequate environment for bacterial growth. Furthermore, root canal preparation using a $\# 60$ file at the working length was promoted to obtain easy access and penetration for the tips of ultrasonic and photodynamic therapy devices into the apical third. In this way, the final shape of root canals allowed the correct manipulation of tips according to the manufacturer's recommendations and a correct sampling procedure.

Counting of colony forming units (CFUs) expressed in $\log \mathrm{CFU} / \mathrm{ml}$ was used to evaluate the effects of the proposed treatments in previous studies $[24,26]$. It allows, in an acceptable way, bacterial quantification from the root canal space [27]. However, the microbiological sample collected was provided only from the main canal, being not possible to assess the presence of bacteria in the depth of dentinal tubules, which can be considered one of the main aetiological factors of failure of root canal therapy due to the persistence of bacteria in areas that are inaccessible by chemomechanical preparation. SEM images in backscattering (BS) at magnifications of 5000x for the canal wall and 10000x for exposed tubule area were used to evaluate the effect of the proposed treatments in the current study. This method allows a better visualization of microorganisms remaining in areas of anatomical complexities, as the depth of dentinal tubules, as well as of the main canal, providing a better quantification of presence of bacteria from the root canal system and evaluation of proposed treatments. Moreover, the evaluation on canal wall and in exposed tubule area allows a real demonstration of the effect of the proposed treatments, since an efficient decontamination should cover not only the microbial content existing in the walls of the main canal, but also microorganisms that penetrate into the depth of dentinal tubules.

Several laser systems have been tested as adjuncts to chemomechanical preparation in endodontic therapy. Highpower lasers have been shown to decrease the presence of endodontic microbiota $[28,29]$. However, these lasers have the potential to cause thermal injury to tissues, such as dentine carbonisation, root ankylosis, cementum melting, root resorption and periradicular necrosis $[30,31]$. In the present study, a low intensity laser was tested in order to evaluate the antimicrobial effects of photodynamic therapy associated or not to sodium hypochlorite on a root canal system infected with Enterococcus faecalis. This therapeutic modality is not based on temperature increases, preventing damage to the attachment tissues and showing satisfactory results of bacterial reduction in the root canal system.

According to the present study, group $4(2.5 \% \mathrm{NaOCl})$ and $5(2.5 \% \mathrm{NaOCl}+\mathrm{PDT})$ had the highest mean of position ranks of SEM images in the canal wall, with no statistically significant differences between them and root canal thirds which were evaluated in these groups. These findings are in accordance of previous study [32], where the use of photodynamic therapy associated to sodium hypochlorite did not improve the potential for decontamination in root canals infected with Enterococcus faecalis. In other hand, group 5
$(2.5 \% \mathrm{NaOCl}+\mathrm{PDT})$ had higher mean of position ranks of SEM images in the canal wall, being statistically different when compared to group 3 (PDT). It can be explained by association of both decontamination protocols. Sodium hypochlorite is the most popular irrigant in the root canal therapy due its high antimicrobial activity, contributing to elimination of Enterococcus faecalis from the root canal system [12]. At the same way, the photosensitizer excited by a light source reacts with molecular oxygen to produce highly reactive oxygen species, which induce injury and death in microorganisms $[8,33]$. Based on the results of the present study, where the highest mean of cleanliness was observed to group $5(\mathrm{PDT}+\mathrm{NaOCl})$ when compared to group 3 (PDT), the use of sodium hypochlorite associated to photodynamic therapy can be an alternative protocol in order to contribute to elimination Enterococcus faecalis from the main root canal.

The exposed tubule area did not reveal differences regarding to effectiveness of group 3 (PDT), group 4 (2.5\% $\mathrm{NaOCl})$ and $5(2.5 \% \mathrm{NaOCl}+\mathrm{PDT})$ since these groups had the highest mean of position ranks, with no statistically significant differences between them and root canal thirds which were evaluated in these groups. The light source generated by a low-power laser can be directed through dentinal tubules, reaching complexity anatomical areas during the performing of photodynamic therapy. Thus, these complexities do not constitute an anatomical barrier in the process of removal of irritants from inside the root canal, such as Enterococcus faecalis. Moreover, figures of Enterococcus faecalis could be found with ruptured membranes and empty spaces (Figure $2-\mathrm{J}-$ arrow) in the groups that used PDT alone or following the use of sodium hypochlorite. Those voids seem to suggest that, in some cases the PDT acts partially, possibly where the photosensitizer and/or the light source did not reach the area completely. Ghinzelli et al. [26] have suggested that passive ultrasonic activation (PUI) improves the delivery of photosensitizer into the root canal system, bringing as consequence a better neutralization of Enterococcus faecalis. The proposed ability of an ultrasonic device to create sonic waves in irrigating solutions deposited inside the root canal might aid in the adherence of methylene blue to the bacterial cellular wall, and also provides better delivery of this photosensitizer along all areas of the root canal space colonised by Enterococcus faecalis. From that, the use of passive ultrasonic irrigation could be tested as alternative to improve the decontamination protocols which were tested in the current study, contributing to eliminate Enterococcus faecalis from the root canal system.

\section{CONCLUSION}

Considering such results, we believe that photodynamic therapy could be an aid in the root canal therapy, contributing to the reduction of microbial content during endodotic therapy. However, the main role in the elimination of bacteria is carried out by conventional chemomechanical 
preparations with a chemical auxiliary substance such as sodium hypochlorite. More studies are needed to assess the removal of bacteria from anatomically complex areas, and to verify the viability of Enterococcus faecalis, which colonises the root canal system.

\section{REFERENCES}

1. Sundqvist G. Bacteriological studies of necrotic dental pulps [thesis] Umea (Suécia): University of Umea; 1976.

2. Kakehashi S, Stanley HR, Fitzgerald RJ. The effects of surgical exposures of dental pulps in germ-free and conventional laboratory rats. Oral Surg Oral Med Oral Pathol 1965;20:340-9. https://doi.org/10.1016/00304220(65)90166-0

3. Haapasalo M. Bacteroides spp in dental root canal infections. Endod Dent Traumatol 1989;5:1-10. https://doi.org/10.1111/j.1600-9657.1989. tb00330.x

4. Molander A, Reit C, Dahlén G, Kvist T. Microbiological status of root-filled teeth with periapical periodontitis. Int Endod J 1998;31:1-7. https://doi. org/10.1046/j.1365-2591.1998.t01-1-00111.x

5. Sundqvist G, Figdor D, Persson S, Sjögren U. Microbiological analysis of teeth with failed endodontic treatment and the outcome of conservative retreatment. Oral Surg Oral Med Oral Pathol Oral Radiol Endod 1998;85: 86-93. https://doi.org/10.1016/S1079-2104(98)90404-8

6. George S, Kishen A, Song KP. The role of environmental changes on monospecies biofilm formation on root canal wall by Enterococcus faecalis. J Endod 2005;31:867-72. https://doi.org/10.1097/01.don. 0000164855.98346.fo

7. Pinheiro ET, Gomes BPFA, Ferraz CCR, Sousa ELR, Teixeira FB, Souza Filho FJ. Microorganisms from canals of root-filled teeth with periapical lesions. Int Endod J 2003;36:1-11. https://doi.org/10.1046/j.13652591.2003.00603.x

8. Tendolkar PM, Baghdayan AS, Shankar N. Pathogenic Enterococci: new developments in the 21st century. Cell Mol Life Sci 2003;60:2622-36. https://doi.org/10.1007/s00018-003-3138-0

9. Figdor D, Davies JK, Sundqvist G. Starvation survival, growth and recovery of Enterococcus faecalis in human serum. Oral Microbiol Immunol 2003;18(4):234-9. https://doi.org/10.1034/j.1399-302X.2003.00072.x

10. Siqueira J, Batista M, Fraga R, de Uzeda M. Antibacterial effects of endodontic irrigants on black-pigmented gram-negative anaerobes and facultative bacteria. J Endod 1998;24:414-6. https://doi.org/10.1016/ S0099-2399(98)80023-X

11. Niazi SA, Clark D, Do T, Gilbert SC, Foschi F, Mannocci F, et al. The effectiveness of enzymic irrigation in removing a nutrient-stressed endodontic multispecies biofilm. Int Endod J 2014;47:756-68. https:// doi.org/10.1111/iej.12214

12. Du T, Wang Z, Shen $Y$, Ma J, Cao Y, Haapasalo M. Effect of longterm exposure to endodontic disinfecting solutions on young and old Enterococcus faecalis biofilms in dentin canals. J Endod 2014;40:509-14. https://doi.org/10.1016/j.joen.2013.11.026

13. Okino LA, Siqueira EL, Santos M, Bombana AC, Figueiredo JA. Dissolution of pulp tissue by aqueous solution of chlorhexidine digluconate and chlorhexidine digluconate gel. Int Endod J 2004;37:38-41. https://doi. org/10.1111/j.1365-2591.2004.00749.x

14. Dutta A, Saunders WP. Comparative evaluation of calcium hypochlorite and sodium hypochlorite on soft-tissue dissolution. J Endod 2012;38:1395-8. https://doi.org/10.1016/j.joen.2012.06.020

15. Tanomaru-Filho M, Leonardo MR, Silva LA, Aníbal FF, Faccioli LH Inflammatory response to different endodontic irrigating solutions. Int Endod J 2002;35:735-739. https://doi.org/10.1046/j.13652591.2002.00544.x

16. Moreira DM, Almeida JFA, Ferraz CCR, Gomes BPFA, Line SRP, Zaia AA Structural analysis of bovine root dentin after use of different endodontics auxiliary chemical substances. J Endod 2009;35:1023-7. https://doi. org/10.1016/j.joen.2009.04.002
17. Santos JN, Carrilho MR, De Goes MF, Zaia AA, Gomes BP, Souza-Filho FJ, Ferraz CC. Effect of chemical irrigants on the bond strength of a selfetching adhesive to pulp chamber dentin. J Endod 2006;32:1088-90. https://doi.org/10.1016/j.joen.2006.07.001

18. Farina AP, Cecchin D, Barbizam JV, Carlini-Júnior B. Influence of endodontic irrigants on bond strength of a self-etching adhesive. Aust Endod J 2011;37:26-30. https://doi.org/10.1111/j.1747-4477.2010.00249.x

19. de Oliveira RR, Novaes AB Jr., Garlet GP, et al. The effect of a single episode of antimicrobial photodynamic therapy in the treatment of experimental periodontitis. Microbiological profile and cytokine pattern in the dog mandible. Lasers Med Sci 2011;26:359-67. https://doi. org/10.1007/s10103-010-0864-z

20. Wainwright M. Photodynamic antimicrobial chemotherapy (PACT). J Antimicrob Chemother 1998;42:13-28. https://doi.org/10.1093/jac/42.1.13

21. Arias-Moliz MT, Ferrer-Luque CM, González-Rodríguez MP, Valderrama MJ, Baca P. Eradication of Enterococcus faecalis biofilms by cetrimide and chlorhexidine. J Endod 2010;36:87-90. https://doi.org/10.1016/j. joen.2009.10.013

22. Chávez de Paz LE, Bergenholtz G, Svensater G. The effects of antimicrobials on endodontic biofilm bacteria. J Endod 2010;36:70-7. https://doi.org/10.1016/j.joen.2009.09.017

23. Ozdemir HO, Buzoglu HD, Calt S, Stabholz A, Steinberg D. Effect of ethylenediaminetetraacetic acid and sodium hypochlorite irrigation on Enterococcus faecalis biofilm colonisation in young and old human root canal dentine: in vitro study. J Endod 2010;36:842-6. https://doi. org/10.1016/j.joen.2010.01.008

24. Grundling GL, Zechin JG, Jarduim WM, de Oliveira SD, de Figueiredo $J A$. Effect of ultrasonics on Enterococcus faecalis biofilm in a bovine tooth model. J Endod 2011;37;1128-33. https://doi.org/10.1016/j. joen.2011.05.006.

25. Sedgley CM, Lennan SL, Appelbe OK. Survival of Enterococcus faecalis in root canals ex vivo. Int Endod J 2005;38:735-42. https://doi.org/10.1111/ j.1365-2591.2005.01009.x

26. Ghinzelli GC, Souza MA, Cecchin D, Farina AP, de Figueiredo JA Influence of ultrasonic activation on photodynamic therapy over root canal system infected with Enterococcus faecalis-an in vitro study. Photodiagnosis Photodyn Ther 2014;11:472-8. https://doi.org/10.1016/j. pdpdt.2014.07.004

27. Peters LB, Wesselink PR, Moorer WR. The fate and the role of bacteria left in root dentinal tubules. Int Endod J 1995;28:95-9. https://doi. org/10.1111/j.1365-2591.1995.tb00166.x

28. Meire MA, De Prijck K, Coenye T, Nelis HJ, De Moor RJ. Effectiveness of different laser systems to kill Enterococcus faecalis in aqueous suspension and in an infected tooth model. Int Endod J 2009;42:351-9. https://doi. org/10.1111/j.1365-2591.2008.01532.x

29. Dewsnup N, Pileggi R, Haddix, J, Nair U, Walker C, Varella CH Comparison of bacterial reduction in straight and curved canals using erbium, chromium: yttrium-scandium-gallium-garnet laser treatment versus a traditional irrigation technique with sodium hypochlorite. J Endod 2010;36:725-8. https://doi.org/10.1016/j.joen.2009.11.017

30. Schoop U, Kluger W, Moritz A, Nedjelik N, Georgopoulos A, Sperr W. Bactericidal effect of different laser systems in the deep layers of dentine. Lasers Surg 2004;35:111-6. https://doi.org/10.1002/lsm.20026

31. Depraet FJ, De Bruyne MA, De Moor RJ. The sealing ability of an epoxy resin root canal sealer after Nd:YAG laser irradiation of the root canal. Int Endod J 2005;38:302-9. https://doi.org/10.1111/j.1365-2591.2005.00948.x

32. Souza LC, Brito PR, de Oliveira JC, Alves FR, Moreira EJ, SampaioFilho HR, et al. Photodynamic therapy with two different photosensitizers as a supplement to instrumentation/irrigation procedures in promoting intracanal reduction of Enterococcus faecalis. J Endod 2010;36:292-6. https://doi.org/10.1016/j.joen.2009.09.041

33. Demidova TN, Hamblin MR. Photodynamic therapy targeted to pathogens. Int J Immunopathol Pharmacol 2004;17:245-54. https://doi. org/10.1177/039463200401700304 